\title{
Progestins regulate genes that can elicit both proliferative and antiproliferative effects in breast cancer cells
}

\author{
SAMI PURMONEN $^{1}$, TOMMI MANNINEN ${ }^{1}$, PASI PENNANEN ${ }^{1}$ and TIMO YLIKOMI ${ }^{1,2}$ \\ ${ }^{1}$ Department of Cell Biology, Medical School, FIN-33014 University of Tampere; \\ ${ }^{2}$ Department of Clinical Chemistry, Tampere University Hospital, Finland
}

Received January 9, 2008; Accepted February 22, 2008

\begin{abstract}
Sex steroid hormone progesterone is known to have profound effects on the growth and differentiation of the normal mammary gland and malignant breast epithelial cells. In vitro progesterone and synthetic progesterone-like compounds (progestins) inhibit breast cancer cell growth. Medroxyprogesterone acetate (MPA) is a synthetic hormone widely used in the adjuvant treatment of advanced breast cancer, hormone replacement therapy and in oral contraceptives. It is a paradoxical hormone, since it inhibits breast cancer cell proliferation, but has also been implicated in increased breast cancer risk. To better understand the molecular mechanism by which cell proliferation and differentiation are regulated by progesterone and MPA in human breast cancer, we utilized cDNA microarray and quantitative real-time RT-PCR methods to identify their target genes. This study describes novel progestin/progesterone target genes in breast cancer cells and, notably, novel target genes that elucidate the underlying molecular mechanism of the dual role progestins play in the breast. A cDNA microarray containing 3000 genes showed notable regulation in 30 and 27 genes by MPA and progesterone, respectively. Only 6 out of the 30 genes regulated by MPA are down-regulated, but no progesterone downregulation was observed. Overlapping in gene regulation by progesterone and MPA occurred, but the majority of genes regulated by these hormones were distinct. Given that progestins both stimulate and inhibit cancer cell growth, we report our findings on novel progestin and progesterone targets, which could explain the paradoxical actions of progestins in the breast.
\end{abstract}

Correspondence to: Dr Sami Purmonen, University of Tampere, Medical School, Department of Cell Biology, FIN-33014, University of Tampere, Finland

E-mail: sami.purmonen@uta.fi

Abbreviations: PR, progesterone receptor; MPA, medroxyprogesterone acetate

Key words: breast cancer, gene regulation, progestins, cDNA microarray

\section{Introduction}

Sex steroid estrogen, progesterone and androgens play a crucial role in the development and differentiation of the normal mammary gland as well as the regulation of breast cancer growth. In the breast cancer cells, progestin has a biphasic action on the cell cycle, since it both stimulates and inhibits breast cancer cell proliferation in vitro (1-3). In these cells, progestins initially stimulate $G_{1}$ cells to enter the $S$ phase, but the prolonged progestin treatment is marked by the growth inhibition of the cells. In the normal breast progestins stimulate cell proliferation in vivo, while in breast tumors and normal breast cells in culture (4) they can inhibit estrogen-stimulated growth, which is often associated with increased differentiation. Progestins, especially medroxyprogesterone acetate (MPA), are therefore used in the adjuvant treatment of advanced breast cancer, hormone replacement therapy (HRT) and in oral contraceptives $(5,6)$.

While the effects of progesterone are mediated by the progesterone receptor (PR) alone, MPA binds to the progesterone, glucocorticoid as well as the androgen receptor (AR) and may exert its antiproliferative effects via different receptors. MPA is a weak AR agonist (7-10), but it activates AR by a mechanism different from other agonists (11). It has been shown that the action of MPA on breast cancer cell proliferation is at least partly due to its intrinsic androgen activity. For example, in an MFM-223 mammary cancer cell line that has high levels of AR, but low levels of PR, its growth is inhibited by DHT or MPA (12). It has recently been shown that decreased AR levels contribute to the failure of response to MPA in patients with metastatic breast cancer (13).

Given that the two hormones mediate their effects partly through different mechanisms, we were interested in finding the specific differences in their gene expression profiles. We compared the gene expression profiles of MPA and progesterone by cDNA microarray analysis in the MCF-7 breast cancer cell line. The human breast cancer cell line MCF-7 possesses androgen, estrogen and progesterone receptors, and is growthinhibited by MPA and progesterone, thereby offering a good model to study the specific role of each of these steroids in the control of breast cancer growth. There are many different strains of MCF-7 cells and we have tested our cell line with a ribonuclease protection assay for GR, AR, PR, ER and ER, 
(14). Although several expression profiles have been published, none describe progesterone- and MPA-regulated genes in the MCF-7 cell line (15-17).

Our data demonstrate that progesterone and MPA partially regulate the same set of genes. However, the majority of genes regulated by these hormones are distinct. The expression of 6 selected genes (AQP3, SGK1, ALCAM, FXYD3/MAT-8, $M U C I N$ and $c-M Y B)$ was analyzed by the quantitative realtime RT-PCR, which confirmed the cDNA microarray results. Furthermore, we describe some novel progesterone/progestin targets that elucidate the underlying molecular mechanism of the dual role progestins play in the breast.

\section{Materials and methods}

Chemicals. Dulbecco's modified Eagle's medium with F12 (DMEM/F12), 17ß-estradiol and medroxyprogesterone acetate were provided by Sigma (St. Louis, MO). Fetal bovine serum (FBS), penicillin-streptomycin and insulin were obtained from Gibco/BRL. Progesterone was purchased from Merck (Darmstadt, Germany).

Cell culture and cell growth assay. MCF-7 cells were cultured in Dulbecco's modified Eagle's medium with F12 (DMEM/F12) supplemented with 5\% FBS, penicillin-streptomycin and $10 \mathrm{ng} / \mathrm{ml}$ insulin. Prior to the experimental studies the cells were cultivated at 2-3 passages in phenol red-free DMEM/F12 supplemented with 5\% dextran-coated, charcoalstripped treated fetal bovine serum, penicillin-streptomycin, $10 \mathrm{ng} / \mathrm{ml}$ insulin and $1 \mathrm{nM} 17 ß$-estradiol. The cells were then plated in triplicate in 96-well plates at a density of $3 \times 10^{3}$ cells per well in the experimental medium. The cells were allowed to attach overnight and the medium was replaced. After $24 \mathrm{~h}$, appropriate steroid hormones in $100 \%$ ethanol were added. Cells were fixed and the number of cells was measured every $24 \mathrm{~h}$ after hormone addition. Briefly, the cells were directly fixed in 96-well plates with $11 \%$ glutaraldehyde by shaking at $500 \mathrm{rpm}$ for $15 \mathrm{~min}$, then washed and air-dried. Crystal violet solution $(0.1 \%)$ was added to stain the fixed cells by shaking for $20 \mathrm{~min}$. Excess dyes were washed away with deionized water and the plates were air-dried before the addition of $10 \%$ acetic acid to extract the cell-bound dyes (18). The optical density of the dye extracts in the plates was measured at a wavelength of $590 \mathrm{~nm}$ using a Victor 1420 multilabel counter (Wallac).

RNA isolation and cDNA microarray hybridization. After treatment for $48 \mathrm{~h}$ with, MPA, progesterone or vehicle, the cells were harvested from $150 \mathrm{~cm}^{2}$ plates and total RNA was extracted using a TRIzol reagent (Life Technologies, Grand Island, NY) according to the manufacturer's protocol. A cDNA microarray was performed according to the manufacturer's instructions. In brief, $20 \mu \mathrm{g}$ of RNA sample from MPA-, progesterone- and vehicle-treated cells was labelled with $\mathrm{Cy}^{\text {TM }}$ 5-dUTP (25 $\mathrm{nM}$ ) by reverse transcription under an oligo $(\mathrm{dT})_{(12-18)}$ primer direction. Concomitantly, an equal amount of RNA sample from the untreated cells was labelled with $\mathrm{Cy}^{\mathrm{TM}} 3$-dUTP $(25 \mathrm{nM})$ as a control. The RNA labelling reactions were performed at $42^{\circ} \mathrm{C}$ for $80 \mathrm{~min}$. After the labelling reaction, RNA was removed from synthesized
cDNA by the addition of $\mathrm{NaOH}$ solution $(1 \mathrm{M})$ followed by neutralisation with Tris- $\mathrm{HCl}(1 \mathrm{M}, \mathrm{pH} 7.5)$. Cy3- and Cy5cDNA were combined together in microcon column (Millipore Corporation, Bedford, USA) and washed four times in TE buffer ( $\mathrm{pH}$ 7.4) by centrifugation. In the final washing step, COT-1 DNA, polyA and yeast tRNA were added to the washing buffer and centrifuged to make the final volume of the labelled cDNA mixture $<10 \mu 1$. For hybridization, a Human2-1 Glass chip containing 3000 cDNA probes (Turku Centre for Biotechnology, Turku, Finland) was pre-treated by succinic anhydride. The labelled cDNA mixture was hybridized with the chip in a humid chamber at $65^{\circ} \mathrm{C}$ overnight. After hybridization, the chip was washed four times by shaking and dried by centrifugation. The fluorescence intensities of $\mathrm{Cy} 3$ and 5 were measured using a ScanArray 4000 laser confocal scanner (GSI Lumonics, Billerica, MA), the hybridization images were analyzed using QuantArray microarray analysis software v3.0 (Packard BioScience) and the data were finally normalized to median by using Excel date normalization macro.

Quantitative real-time RT-PCR analysis. Reverse transcription (RT) and real-time PCR were performed separately. The total RNA from each sample was reverse-transcribed using a high capacity cDNA archive kit (Applied Biosystems, USA) and PCR reactions were performed in MicroAmp optical 96well reaction plates using a SYBR-Green PCR master mix kit (Applied Biosystems) following the manufacturer's instructions. Briefly, for reverse transcription, $5 \mu \mathrm{g}$ of RNA dissolved in $50 \mu \mathrm{l}$ PCR-compatible buffer was mixed with $50 \mu 1$ of $2 \mathrm{x}$ RT master mix [10 $\mu 1$ of $10 \mathrm{x}$ reverse transcription buffer, $4 \mu 1$ of $25 \mathrm{x}$ dNTPs, $10 \mu 1$ of $10 \mathrm{x}$ random primers, $5 \mu 1$ of multiscribe reverse transcriptase $(50 \mathrm{U} / \mu \mathrm{l})$ and $21 \mu \mathrm{l}$ of nuclease-free $\mathrm{H}_{2} \mathrm{O}$ ], RT was performed at $25^{\circ} \mathrm{C}$ for $10 \mathrm{~min}$ followed by $37^{\circ} \mathrm{C}$ for $2 \mathrm{~h}$ in the programmable thermal controller (MJ Research, Inc., Watertown, USA). For real-time PCR, 30 ng of cDNA was combined with the primers and $2 x$ SYBR-Green PCR master mix to the final volume of $30 \mu 1$ per reaction. Real-time PCR was performed at $95^{\circ} \mathrm{C}$ for $10 \mathrm{~min}$ followed by 40 cycles at $95^{\circ} \mathrm{C}$ for $15 \mathrm{sec}$ and $60^{\circ} \mathrm{C}$ for $1 \mathrm{~min}$ on an ABI PRISM 7000 Detection System (Applied Biosystems). The PCR product was examined by dissociation curve analysis to verify the specific products.

The data were analyzed with ABI PRISM 7000 SDS software and normalized to the human acidic ribosomal phosphoprotein P0 (RPLP0) as the endogenous control to verify uniform RNA loading in the experiments. The final results were expressed as the $\mathrm{N}$-fold difference in the gene expression between the treated and control sample as described (19). The values used for calculating the formula were obtained from the corresponding standard curve. The standard curves of the endogenous controls and target genes were made by a series of dilutions of the treated samples.

All primers used were designed by using Primer Express v2.0 software (Applied Biosystems). To avoid the amplification of any genomic DNA, the forward and reverse primers for each gene were chosen from different exons. BLASTN searches were performed to confirm the specificity of the primer sequences. The primers for selected genes are listed in Table I. 
Table I. Genes and their primer sequences used in the real-time RT-PCR. ${ }^{\mathrm{a}}$

\begin{tabular}{lll}
\hline Gene & Forward primer & \multicolumn{1}{c}{ Reverse primer } \\
\hline MUC1 & $5^{\prime}$-tgccttggctgtctgtcagt-3' & $5^{\prime}$-cccgggctggaaagatgt-3' \\
AQP3 & $5^{\prime}$-gccggcatctttgctacct-3' & $5^{\prime}$-tgtgcctatgaactggtggtcaaagaa-3' \\
ALCAM & $5^{\prime}$-tctgctcttctgcctcttgatct-3' & $5^{\prime}$-tatgctgaatttacagtataccatccaa-3' \\
SGK1 & $5^{\prime}$-ctcccccttttaacccaaatg-3' & $5^{\prime}$-gggacaggctcttcggtaaac-3' \\
c-MYB & $5^{\prime}$-agacaatgttctcaaagcatttacagtac-3' & $5^{\prime}$-aggatgcaggttcccaggta-3' \\
FXYD3/MAT-8 & $5^{\prime}$-ccacaactgccagcaatcct-3' & $5^{\prime}$-cgccctaagcaaacctcact-3' \\
RPLP0 & $5^{\prime}$-aatctccaggggcaccatt-3' & $5^{\prime}$-cgctggctcccactttgt-3' \\
\hline
\end{tabular}

aThe forward and reverse primers for each gene were chosen from different exons. BLASTN searches were performed to confirm the specificity of the primer sequences.

Table II. Genes showing the expression ratio $>2$ or $<2$ in MCF-7 cells treated by MPA for 48 h. ${ }^{\text {a }}$

\begin{tabular}{|c|c|c|c|}
\hline Accession no. & Gene name & Description & -Fold \\
\hline R32848 & S100P & $\mathrm{S} 100$ calcium-binding protein $\mathrm{P}$ & 18.5 \\
\hline R92737 & AQP3 & Aquaporin 3 & 4.4 \\
\hline AA126009 & FXYD3/MAT-8 & FXYD domain-containing ion transport regulator 3 & 3.8 \\
\hline AA459100 & TPD52 & Tumor protein D52 & 3.6 \\
\hline H23187 & CA2 & Carbonic anhydrase II & 3.5 \\
\hline $\mathrm{T} 77840$ & Dlg5 & Disc large homolog 5 & 3.5 \\
\hline AA488073 & MUC1 & Mucin 1 & 3.4 \\
\hline AA486082 & SGK1 & Serum/glucocorticoid-regulated kinase & 3.3 \\
\hline R93124 & $2-\alpha-H S D$ & Aldo-keto reductase family 1, member $\mathrm{C} 1$ & 3.0 \\
\hline AA070226 & SEPP1 & Selenoprotein P & 3.0 \\
\hline AA434373 & ELF3 & E74-like factor 3 & 2.8 \\
\hline R62817 & EPB72 & Erythrocyte membrane protein band 7.2 & 2.6 \\
\hline H77597 & MT1 & Metallothionein $1 \mathrm{H}$ & 2.5 \\
\hline R39862 & ALCAM & Activated leucocyte cell adhesion molecule & 2.5 \\
\hline H53340 & MT1G & Metallothionein $1 \mathrm{G}$ & 2.4 \\
\hline H50323 & FAS & Fatty acid synthase & 2.3 \\
\hline R63065 & GST5 & Glutathione S-transferase M3 & 2.3 \\
\hline N80129 & MT1XL & Metallothionein 1L & 2.3 \\
\hline AA425746 & RUNX1 & Runt-related transcription factor 1 & 2.1 \\
\hline H45668 & KLF4 & Kruppel-like factor 4 & 2.1 \\
\hline H72028 & GSN & Gelsolin & 2.1 \\
\hline $\mathrm{T} 73556$ & ACSL1 & Fatty-acid-coenzyme A ligase, long-chain & 2.1 \\
\hline N20475 & CTSD & Cathepsin D & 2.0 \\
\hline AA496576 & NFE2L & Nuclear factor (erythroid-derived 2)-like 1 & 2.0 \\
\hline AA434397 & ITGB5 & Integrin, 35 & -3.3 \\
\hline N49284 & c-MYB & V-myb avian myeloblastosis viral oncogene homolog & -2.5 \\
\hline AA027012 & KDR/VEGFR2 & Kinase insert domain receptor & 2.5 \\
\hline AA463257 & ITGA2/CD49B & Integrin, $\alpha-2$ & -2.5 \\
\hline R43817 & NPY1R & Neuropeptide Y receptor Y1 & -2.0 \\
\hline AA464532 & THBS1 & Thrombospondin 1 & -2.0 \\
\hline
\end{tabular}

aThe cDNA chip contained each gene in triplicate. Results are the average fold changes of triplicates in two independent experiments. The genes are listed in descending order. 
A

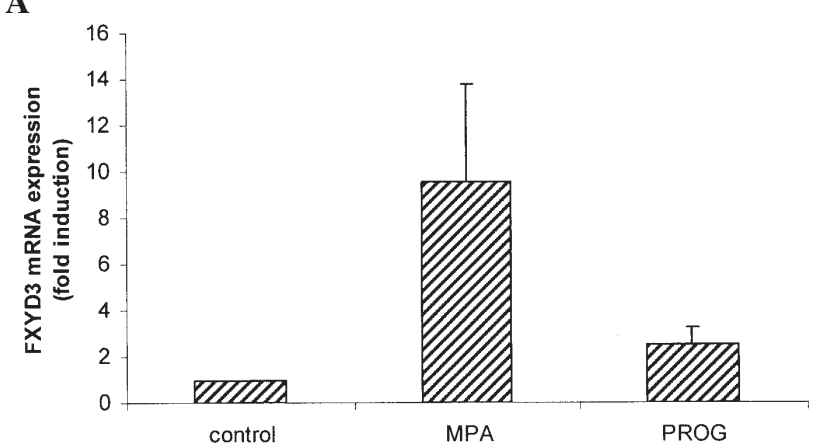

C

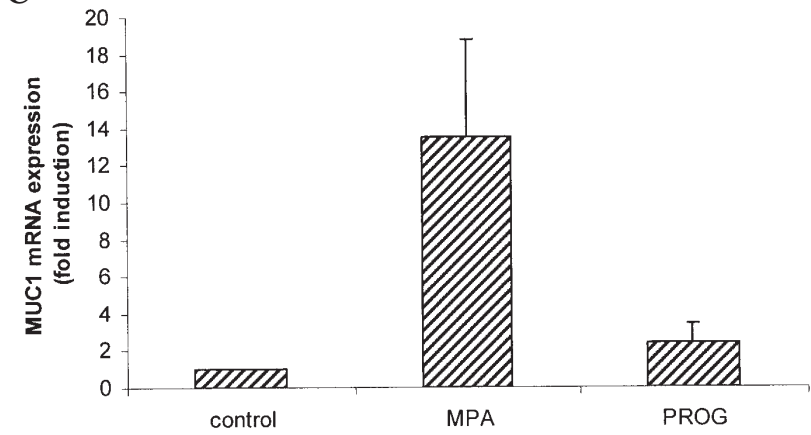

B

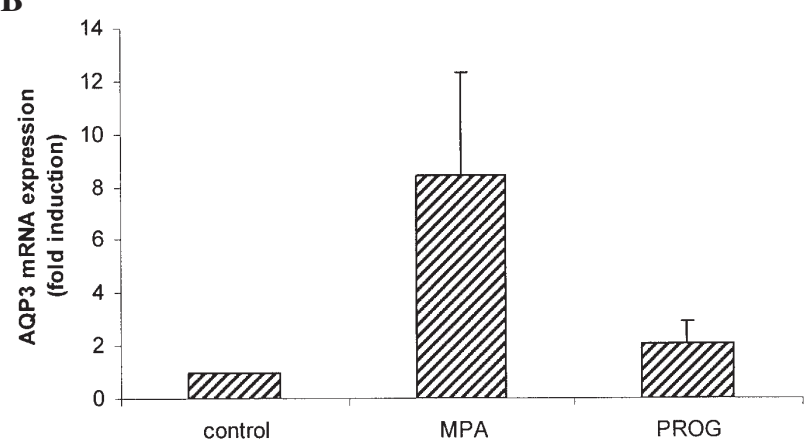

D

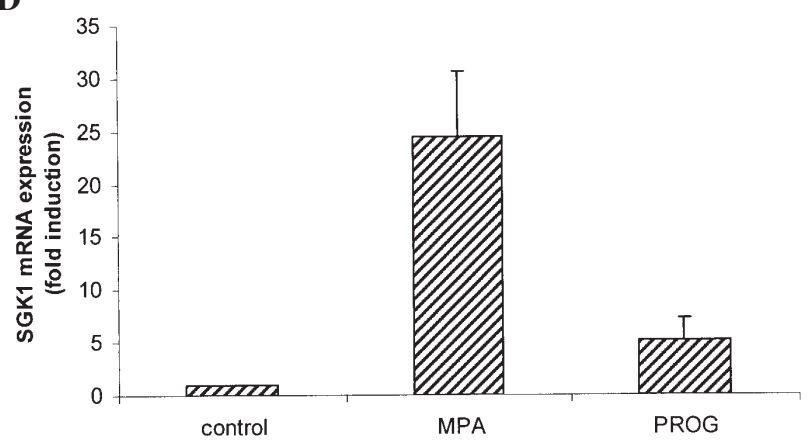

Figure 1. A quantitative real-time RT-PCR analysis of selected MPA and progesterone up-regulated genes. MCF-7 cells cultured in the insulin-supplemented serum in the presence of $1 \mathrm{nM}$ 17B-estradiol were treated with ethanol vehicle, $10 \mathrm{nM}$ MPA or $10 \mathrm{nM}$ progesterone for $48 \mathrm{~h}$. The cells were then harvested and RNA was used for quantitative real-time RT-PCR. Results are expressed as the means ( \pm SD) of two independent experiments performed in triplicate. (A) $F X Y D 3 / M A T-8$, (B) AQP3, (C) MUCIN1 and (D) SGK1.

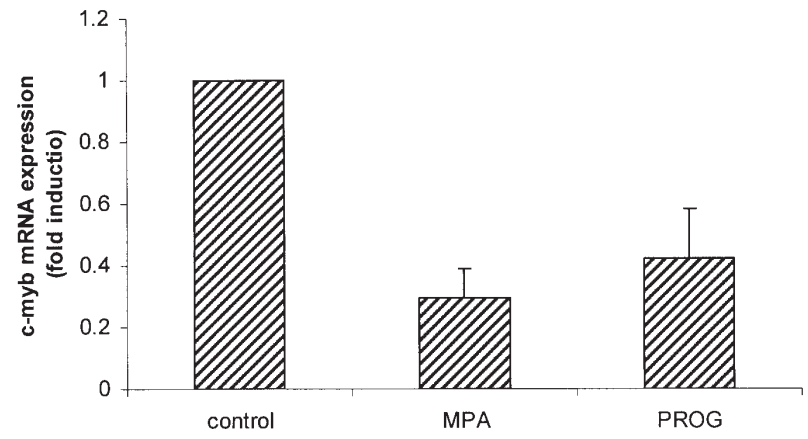

Figure 2. c-MYB proto-oncogene is down-regulated by progesterone and MPA. MCF-7 cells cultured in the insulin-supplemented serum in the presence of $1 \mathrm{nM}$ 17ß-estradiol were treated with ethanol vehicle, $10 \mathrm{nM}$ MPA or $10 \mathrm{nM}$ progesterone for $48 \mathrm{~h}$. The cells were then harvested and RNA was used for quantitative real-time RT-PCR. Results are expressed as the means $( \pm \mathrm{SD})$ of two independent experiments performed in triplicate.

\section{Results}

Growth inhibition of MCF-7 cells by MPA and progesterone. The growth of MCF-7 cells was inhibited by $10 \mathrm{nM}$ MPA and progesterone. MCF-7 cells were treated with $10 \mathrm{nM}$ MPA, $10 \mathrm{nM}$ progesterone or vehicle in the presence of $1 \mathrm{nM}$ estradiol. The growth-inhibitory effect by MPA and progesterone after 6 days was 20 and $10 \%$ respectively $(20,21)$.

Identification of MPA and progesterone-regulated genes (cDNA microarray hybridization). To examine the molecular

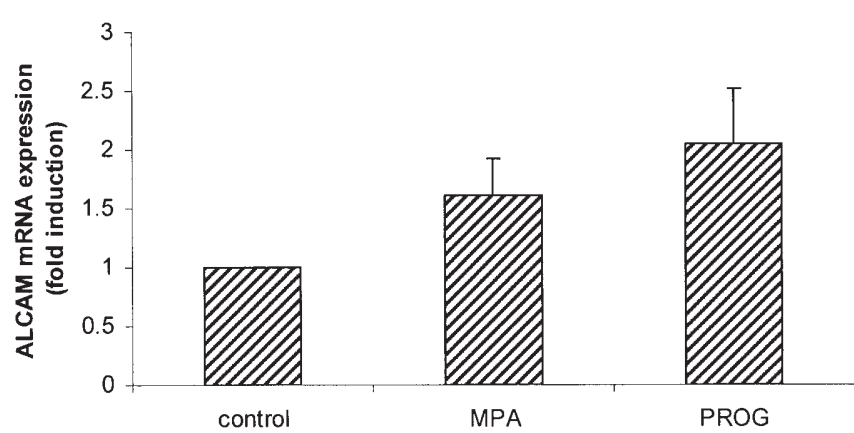

Figure 3. ALCAM is regulated by progesterone but not by MPA. MCF-7 cells cultured in the insulin-supplemented serum in the presence of $1 \mathrm{nM}$ $17 B$-estradiol were treated with ethanol vehicle, $10 \mathrm{nM}$ MPA or $10 \mathrm{nM}$ progesterone for $48 \mathrm{~h}$. The cells were then harvested and RNA was used for quantitative real-time RT-PCR. Results are expressed as the means $( \pm \mathrm{SD})$ of two independent experiments performed in triplicate.

mechanism of the synthetic progestin MPA and progesterone, we compared the gene expression profiles of the MPA and progesterone by cDNA microarray analysis in the MCF-7 breast cancer cell line. Total RNA was isolated from the cells cultured in the presence of $1 \mathrm{nM}$ estrogen treated with vehicle, progesterone $(10 \mathrm{nM})$ and MPA $(10 \mathrm{nM})$ for $48 \mathrm{~h}$.

Tables II and III list genes that were regulated at least 2fold by MPA and progesterone, respectively. The cDNA chip used in this study contained each gene in triplicate. Fold changes are the average of the triplicates in two independent experiments. 
Table III. Genes showing an expression ratio of $>2$ in MCF-7 cells treated by progesterone for $48 \mathrm{~h}^{\mathrm{a}}$

\begin{tabular}{|c|c|c|c|}
\hline Accession no. & Gene name & Description & -Fold \\
\hline N20475 & CTSD & Cathepsin D & 5.5 \\
\hline $\mathrm{R} 32848$ & S100P & Calcium-binding protein $\mathrm{P}$ & 4.5 \\
\hline AA434115 & CHI3L1 & Chitinase-3-like protein 1 precursor & 4.0 \\
\hline AA485959 & KRT7 & Keratin 7 & 3.6 \\
\hline N54596 & IGF2 & Insulin-like growth factor 2 & 3.5 \\
\hline AA126009 & FXYD3/MAT-8 & FXYD domain-containing ion transport regulator 3 & 3.3 \\
\hline R39862 & ALCAM & Activated leucocyte cell adhesion molecule & 3.0 \\
\hline N38990 & GYPE & Glycophorin 3 & 3.0 \\
\hline T77840 & DLG5 & Discs, large homolog 5 & 3.0 \\
\hline N75028 & PSPHL & Phosphoserine phosphatase-like & 2.9 \\
\hline $\mathrm{H} 23187$ & CA2 & Carbonic anhydrase II & 2.9 \\
\hline N71003 & PDCD4 & Programmed cell death 4 & 2.8 \\
\hline AA410429 & VASP & Vasodilator-stimulated phosphoprotein & 2.7 \\
\hline AA411554 & SLC25A16 & Solute carrier family 25 member 16 & 2.7 \\
\hline R10973 & PAPPA & Pregnancy-associated plasma protein A & 2.6 \\
\hline $\mathrm{R} 01638$ & CTDSPL & Small CTD phosphatase 3 & 2.5 \\
\hline AA434373 & ELF3 & E74-like factor 3 & 2.5 \\
\hline W93472 & CNGA1 & Cyclic nucleotide gated channel $\alpha 1$ & 2.5 \\
\hline AA402960 & RNF5 & Ring finger protein 5 & 2.4 \\
\hline AA668595 & TP53I3 & Tumor protein p53 inducible protein 3 & 2.4 \\
\hline H14343 & $\mathrm{CDC} 25 \mathrm{~B}$ & Cell division cycle 25B & 2.3 \\
\hline AA425853 & SFPQ & PTB-associated splicing factor & 2.3 \\
\hline N66852 & ORC2L & Origin recognition complex subunit 2 & 2.2 \\
\hline AA452848 & AAMP & Angio-associated, migratory cell protein & 2.2 \\
\hline AA453293 & PDE4B & Phosphodiesterase 4B & 2.1 \\
\hline AA598659 & NUMA1 & Nuclear mitotic apparatus protein 1 & 2.1 \\
\hline N98524 & F10 & Coagulation factor $\mathrm{X}$ & 2.1 \\
\hline
\end{tabular}

${ }^{\mathrm{a}} \mathrm{A}$ cDNA chip contained each gene in triplicate. Results are the average fold changes of the triplicates in two independent experiments. The genes are listed in descending order.

Of the 30 genes regulated by MPA only 6 were downregulated. Progesterone up-regulated 27 genes 7 (E74-like factor 3/elf3, carbonic anhydrase II, ALCAM, cathepsin D, S100P, D $\lg 5$ and FXYD3/MAT-8) of which were also regulated by MPA. As expected, progesterone was a less potent regulator than MPA. Several genes found in this study have previously been reported to be progesterone- or progestinregulated, confirming the reliability of our data. The genes are: S100P, Dlg5, tumor protein D52, cathepsin D, neuropeptide $Y$ receptor $Y 1$ and carbonic anhydrase II $(16,17,21)$. Many, however, were not known to be progestin-responsive and therefore represent novel progestin targets.

Quantitative real-time RT-PCR analysis. To validate the expression results of the cDNA microarray hybridization, the quantitative real-time RT-PCR analyses were utilized. The selected genes and their primer sequences (6 genes for MPA and progesterone) are listed in Table I. The selected genes were confirmed to be regulated either by MPA and progesterone, or progesterone alone as suggested by cDNA microarray analysis (Figs. 1, 2 and 3). FXYD3/MAT-8, AQP3, MUCIN and $S G K 1$ are all up-regulated by MPA and to a lesser extent by progesterone (Fig. 1A-D). Of the 6 genes tested, SGK1 shows the most remarkable regulation under MPA treatment ( 24 -fold). The stimulation by progesterone is less pronounced, but notable ( 5-fold). MUCIN and FXYD3/MAT-8 are also strongly stimulated by MPA ( 13.5 - and $\sim 9.5$-fold), but progesterone stimulation is much weaker. c-MYB is down-regulated by the two hormones ( - 3.5-fold by MPA and $\sim-2.3$-fold by progesterone) (Fig. 2). ALCAM is specifically up-regulated by progesterone (Fig. 3).

\section{Discussion}

To investigate the molecular basis for progestin- and progesterone-induced inhibition of breast cancer cell 
proliferation, we used cDNA microarray to detect the MPAand progesterone-induced alterations of the gene expression in MCF-7 cells. The cDNA microarray of 3000 genes (each in triplicate) showed notable regulation in 30 and 27 genes by MPA and progesterone, respectively. Only 6 out of the 30 genes regulated by MPA are down-regulated and no progesterone down-regulation was observed.

To validate the microarray results, genes from each category were chosen for further analysis: four MPA upregulated, one MPA down-regulated and one progesterone up-regulated. The regulation of $F X Y D 3 / M A T-8, A Q P 3$, $M U C I N, S G K 1, c-M Y B$ and $A L C A M$ were individually tested by quantitative real-time RT-PCR. These genes were selected because of their obvious or possible relevance to breast cancer or to known pathways which may explain the dual role of progestins. FXYD3/MAT-8, AQP3, MUCIN and SGK1 are all induced in response to the treatment of cells with MPA and to a lesser extent by progesterone, while c-MYB is downregulated by the two hormones and $A L C A M$ is up-regulated only by progesterone. All the selected genes from the MPA category were tested by quantitative real-time RT-PCR for progesterone and MPA regulation, although the initial expression profiling with microarray suggested the genes be regulated only by MPA. Based on the quantitative RT-PCR results, all of the selected genes were found to be regulated not only by MPA but also by progesterone. This is not unexpected, since quantitative RT-PCR is a more accurate method of identifying quantitative differences in the gene expression than microarray profiling, especially when the genes have low expression levels. A recent study showed that quantitative RT-PCR often fails to validate differences in gene expression observed by gene expression profiling (15).

MPA up-regulated genes. The first gene tested, FXYD3/MAT-8, is a mammary tumor $8 \mathrm{kDa}$ transmembrane protein, that is expressed in primary human breast tumors and in human breast tumor cell lines and serve as a $\mathrm{Na}, \mathrm{K}$-ATPase regulator $(22,23)$. Mat-8 is a marker of a specific cell type preferentially transformed by the action of $\mathrm{Neu}$ and Ras, but not Myc oncoproteins during murine mammary carcinogenesis (24). It is up-regulated in prostate cancer and its siRNA-mediated inhibition of the expression decreases the proliferation of human prostate carcinoma cells (25). FXYD3/MAT-8 is therefore an example of the genes that are induced by progestins and are potentially proliferation-related. FXYD3/ MAT-8 up-regulation (along with $M U C 1$, see below) could point to the proliferative facet of the dual role progestins play in the breast.

The second gene analyzed, the epithelial cancer-associated antigen MUCIN 1 ( $m u c 1 / c d 227)$, is a membrane-associated glycoprotein expressed by many types of ductal epithelia, is expressed in a wide variety of tumors and is considered to function as an anti-adhesion molecule which inhibits cell-tocell interactions (26-28). Several studies have demonstrated the regulation of MUC1 expression by steroid hormones, including estrogens, glucocorticoids and androgens $(29,30)$. Although MUC1 is known to be progesterone-regulated (stimulated or repressed) in some organ systems, only one report exists suggesting that the expression of cellular and secreted MUC1 is stimulated by progesterone in the breast cancer cell line (31-33). To our knowledge, however, the effect of progestins in MUC1 mRNA expression has yet to be demonstrated.

Our finding that the MUC1 mRNA level is elevated as late as $48 \mathrm{~h}$ after progestin treatment may partly explain the harmful actions of progestins in the breast. Considering the role of $M U C 1$ as an anti-adhesive molecule, its up-regulation by progesterone in breast cancers may enhance cell proliferation and/or metastatic spread. Our finding is supported by the fact that MUC1 is overexpressed in breast cancer $(34,35)$.

The third gene tested, a serum and glucocorticoidinducible serine/threonine protein kinase ( $S G K 1$ ), was originally identified as an immediate early gene induced by glucocorticoids (36). Emerging evidence thereafter has established SGK1 as a vital regulatory molecule in coordinating extracellular signals (steroid hormones, protein growth factors and other environmental cues) and intracellular processes in controlling cell proliferation and survival. An original study by Webster et al reports on the SGK1 induction by glucocorticoids and serum, but not by progesterone in Con 8 rat mammary tumor cells (36). We showed herein that in human MCF-7 mammary tumor cells, SGK1 is markedly induced by MPA and progesterone (Fig. 1D). This is expected, since glucocorticoid and progesterone response elements are identical and progestins are supposed to regulate $S G K 1$ expression via PR. MPA can also act via the glucocorticoid receptor. The function of SGK1 is poorly understood, but it is now recognized that SGK1 has a very important role in crosstalk that can couple anti-proliferative and proliferative cell signalling pathways (37). $S G K 1$ is transcriptionally regulated in rat mammary tumor cells by serum under proliferative conditions or by glucocorticoids that induce a $G_{1}$ cell cycle arrest (38) and SGK1 actively shuttles between the nucleus (in $\mathrm{S}$ and $\mathrm{G} 2 / \mathrm{M}$ ) and the cytoplasm (in G1) in synchrony with the cell cycle (37). Therefore, it has been proposed that SGK1 could maintain the cells in a growth-suppressed state while localized to the cytoplasm and facilitate proliferation as a result of its nuclear-cytoplasmic shuttling during the cell cycle in mammary tumor cells $(37,39)$. The mechanism whereby progestins affect cell growth through $S G K 1$ calls for further investigation. Whether the progestins cause SGK1 localization to the cytoplasm or nucleus can be an important determinant as to which of the pathways (stimulatory or inhibitory) is activated. This finding clarifies the capacity progestins have in breast either to increase or decrease growth depending on the cell context and other milieu.

MPA down-regulated genes. Six MPA down-regulated genes were identified in this study: thrombospondin 1 (THBS1), integrin $\alpha$-2 (ITG $\alpha 2)$, vascular endothelial growth factor receptor 2, (VEGFR2/KDR), integrin $\beta-5$ (ITG $\beta 5)$, neuropeptide $Y$ receptor $Y 1$ (NPY1-R) and MYB proto-oncogene $(c-M Y B)$. Of these, neuropeptide Y receptor Y1 and c-MYB are known progestin targets (17) and thrombospondin 1 is overexpressed in breast carcinomas (40).

$c-M Y B$ is clearly down-regulated by MPA and progesterone (Fig. 2), and is an interesting progestin target. The myb gene family consists of three members: A, B and c-MYB, which encode nuclear proteins that function as transcriptional trans- 
activators. The human c-MYB proto-oncogene is the cellular progenitor of the viral v-MYB oncogene. The expression of c$M Y B$ correlates with proliferation and decreases during differentiation. Several studies have shown that c-MYB downregulation is needed for terminal differentiation, constitutive c- $M Y B$ expression blocks differentiation and antisense oligonucleotides targeting $\mathrm{c}-M Y B$ block the proliferation of human hematopoietic cells (2,41-43). MYB oncogene amplification has been observed in hereditary BRCA1 breast cancer (44) and there is a strong association between c-MYB and estrogen receptor expression in breast cancer (45). Notably, c-MYB is also induced in response to estrogen treatment in the MCF-7 cells (46). As estrogens are strong proliferation stimulants, it appears that opposing the estrogen induced effect in $c-M Y B$ expression, progestins could potentiate differentiation and decrease the proliferation of breast cancer cells.

Progesterone-regulated genes. Progesterone up-regulated 27 genes by $>2$-fold, but no down-regulation was observed, as assessed by cDNA microarray analysis. In general, there is overlapping in gene regulation by progesterone and MPA, but the majority of genes regulated by these hormones are distinct. For those genes that are regulated by the two hormones, progesterone regulation is less pronounced.

We selected one progesterone-regulated gene for further analysis. The activated-leukocyte cell-adhesion molecule (ALCAM) is a glycoprotein of the immunoglobulin superfamily. ALCAM is involved with cellular adhesion, proliferation and tumor progression, and is specifically induced by progesterone, but not MPA, as verified by quantitative RT-PCR (Fig. 3). Studies have shown that $A L C A M$ decreases the proliferation and adhesion of breast cancer cells to each other and this reduced expression indicates a more aggressive phenotype and poor prognosis (47). Its upregulation by progesterone is consistent with the antiproliferative effects of progesterone in vitro.

Multifaceted gene regulation by progestins. Certain conclusions can be drawn at this stage. A vast majority of MPA and/or progesterone target genes found in this study are up-regulated. This phenomenon has also been observed in previous studies $(16,17,48)$. It has been proposed that genes which are up-regulated show larger differences in the expression level upon progestin treatment and are therefore identified more easily (48). While this may be partially true, it appears however, that down-regulated genes are uncommon. Relatively few progesterone down-regulated genes have been identified thus far. In studies by Richer et al only 12 such genes were identified using chips consisting of 5,600 fulllength human genes (16). Using the same chip, Wan and Nordeen identified 34 down-regulated genes, when using the more potent PR agonist, the synthetic progestin R5020 (17). Our data are therefore consistent with previously published data. Using the chip containing $3000 \mathrm{cDNA}$ probes, we found 6 MPA down-regulated genes, but no progesterone-induced gene down-regulation was observed.

Previous studies have shown that at early time points (2 and $6 \mathrm{~h}$ ), progestins induce certain genes associated with cell cycle progression and/or down-regulate growth-suppressive genes $(16,49)$. Based on what we know about the biphasic role of progestins, that is to be expected since during the first $24 \mathrm{~h}$ progestins stimulate cell growth. Of particular note, therefore, is our finding that certain genes that can potentially exacerbate harmful effects of progestins, are still up-regulated after $48 \mathrm{~h}$. Evidence indicates that under differing conditions, the balance between growth promoting and inhibiting factors, determine whether a stimulatory or inhibitory pathway will predominate.

Our results also show that all those MPA-regulated genes whose expression was verified by quantitative real-time RTPCR, are also progesterone-regulated, but to a lesser extent. This was to be expected, since MPA is a more potent progestin and quantitative RT-PCR is a more accurate method of detecting the expression differences. It is not known, however, whether this is true for all MPA-regulated genes. The study by Bray et al suggests that differentially regulated genes by different progestins through PR are rare at least in the T47DCo cell line (15).

In summary, we have identified several novel progestin (MPA) and progesterone target genes in the MCF-7 breast cancer cell line. The majority of progestin-regulated genes are up-regulated. Of particular note for this study is that certain up-regulated genes are growth-associated, which may explain the harmful effects progestins elicit in the breast. Our data therefore point to the capacity progestins possess at a transcriptional level either to stimulate or inhibit cell growth. It is probably the balance between growth promoting and inhibiting factors that determine whether proliferative or antiproliferative effects take place.

\section{Acknowledgements}

We are indebted to Dr Kati Porkka for advice. We thank Ms. Hilkka Mäkinen and Ms. Mirja Hyppönen for excellent technical assistance. This study was supported by grants from Pirkanmaa Cancer Society and Medical Research Fund of Tampere University Hospital.

\section{References}

1. Schoonen WG, Joosten JW and Kloosterboer HJ: Effects of two classes of progestagens, pregnane and 19-nortestosterone derivatives, on cell growth of human breast tumor cells: I. MCF-7 cell lines. J Steroid Biochem Mol Biol 55: 423-437, 1995.

2. Sutherland RL, Hall RE, Pang GY, Musgrove EA and Clarke CL: Effect of medroxyprogesterone acetate on proliferation and cell cycle kinetics of human mammary carcinoma cells. Cancer Res 48: 5084-5091, 1988.

3. Musgrove EA, Lee CS and Sutherland RL: Progestins both stimulate and inhibit breast cancer cell cycle progression while increasing expression of transforming growth factor alpha, epidermal growth factor receptor, c-fos, and c-myc genes. Mol Cell Biol 11: 5032-5043, 1991 .

4. Gompel A, Malet C, Spritzer P, Lalardrie JP, Kuttenn F and Mauvais-Jarvis P: Progestin effect on cell proliferation and 17 beta hydroxysteroid dehydrogenase activity in normal human breast cells in culture. J Clin Endocrinol Metab 63: 1174-1180, 1986.

5. Haller DG and Glick JH: Progestational agents in advanced breast cancer: an overview. Semin Oncol 13: 2-8, 1986.

6. Sedlacek SM and Horwitz KB: The role of progestins and progesterone receptors in the treatment of breast cancer. Steroids 44: 467-484, 1984.

7. Bardin CW, Brown T, Isomaa VV and Janne OA: Progestins can mimic, inhibit and potentiate the actions of androgens. Pharmacol Ther 23: 443-459, 1983. 
8. Labrie F, Poulin R, Simard J, et al: Interactions between estrogens, androgens, progestins and glucocorticoids in ZR-75-1 human breast cancer cells. Ann NY Acad Sci 595: 130-148, 1990

9. Raynaud JP, Bouton MM, Moguilewsky M, et al: Steroid hormone receptors and pharmacology. J Steroid Biochem 12: 143-157, 1980.

10. Mowszowicz I, Bieber DE, Chung KW, Bullock LP and Bardin CW: Synandrogenic and antiandrogenic effect of progestins: comparison with nonprogestational antiandrogens. Endocrinology 95: 1589-1599, 1974.

11. Kemppainen JA, Langley E, Wong CI, Bobseine K, Kelce WR and Wilson EM: Distinguishing androgen receptor agonists and antagonists: distinct mechanisms of activation by medroxyprogesterone acetate and dihydrotestosterone. Mol Endocrinol 13: 440-454, 1999.

12. Hackenberg R, Hawighorst T, Filmer A, Nia AH and Schulz KD: Medroxyprogesterone acetate inhibits the proliferation of estrogen- and progesterone-receptor negative MFM-223 human mammary cancer cells via the androgen receptor. Breast Cancer Res Treat 25: 217-224, 1993.

13. Buchanan G, Birrell SN, Peters AA, et al: Decreased androgen receptor levels and receptor function in breast cancer contribute to the failure of response to medroxyprogesterone acetate. Cancer Res 65: 8487-8496, 2005.

14. Sarvilinna N, Eronen H, Miettinen S, Vienonen A and Ylikomi T: Steroid hormone receptors and coregulators in endocrineresistant and estrogen-independent breast cancer cells. Int J Cancer 118: 832-840, 2006.

15. Bray JD, Jelinsky S, Ghatge R, et al: Quantitative analysis of gene regulation by seven clinically relevant progestins suggests a highly similar mechanism of action through progesterone receptors in T47D breast cancer cells. J Steroid Biochem Mol Biol 97: 328-341, 2005.

16. Richer JK, Jacobsen BM, Manning NG, Abel MG, Wolf DM and Horwitz KB: Differential gene regulation by the two progesterone receptor isoforms in human breast cancer cells. J Biol Chem 277: 5209-5218, 2002.

17. Wan Y and Nordeen SK: Overlapping but distinct gene regulation profiles by glucocorticoids and progestins in human breast cancer cells. Mol Endocrinol 16: 1204-1214, 2002.

18. Kueng W, Silber E and Eppenberger U: Quantification of cells cultured on 96-well plates. Anal Biochem 182: 16-19, 1989.

19. Pfaffl MW: A new mathematical model for relative quantification in real-time RT-PCR. Nucleic Acids Res 29: e45, 2001.

20. Ahola TM, Purmonen S, Pennanen P, Zhuang YH, Tuohimaa P and Ylikomi T: Progestin upregulates G-protein-coupled receptor 30 in breast cancer cells. Eur J Biochem 269: 2485-2490, 2002.

21. Purmonen S, Ahola TM, Pennanen P, et al: HDLG5/KIAA0583, encoding a MAGUK-family protein, is a primary progesterone target gene in breast cancer cells. Int J Cancer 102: 1-6, 2002

22. Crambert G, Li C, Claeys D and Geering K: FXYD3 (Mat-8), a New Regulator of Na,K-ATPase. Mol Biol Cell 16: 2363-2371, 2005.

23. Morrison BW, Moorman JR, Kowdley GC, Kobayashi YM, Jones LR and Leder P: Mat-8, a novel phospholemman-like protein expressed in human breast tumors, induces a chloride conductance in Xenopus oocytes. J Biol Chem 270: 2176-2182, 1995.

24. Morrison BW and Leder P: Neu and ras initiate murine mammary tumors that share genetic markers generally absent in c-myc and int-2-initiated tumors. Oncogene 9: 3417-3426, 1994.

25. Grzmil M, Voigt S, Thelen P, Hemmerlein B, Helmke $K$ and Burfeind P: Up-regulated expression of the MAT-8 gene in prostate cancer and its siRNA-mediated inhibition of expression induces a decrease in proliferation of human prostate carcinoma cells. Int J Oncol 24: 97-105, 2004.

26. Braga VM, Pemberton LF, Duhig T and Gendler SJ: Spatial and temporal expression of an epithelial mucin, Muc-1, during mouse development. Development 115: 427-437, 1992.

27. Gendler SJ: MUC1, the renaissance molecule. J Mammary Gland Biol Neoplasia 6: 339-353, 2001.

28. Makiguchi Y, Hinoda Y and Imai K: Effect of MUC1 mucin, an anti-adhesion molecule, on tumor cell growth. Jpn J Cancer Res 87: 505-511, 1996.

29. Evangelou A, Letarte M, Marks A and Brown TJ: Androgen modulation of adhesion and antiadhesion molecules in PC-3 prostate cancer cells expressing androgen receptor. Endocrinology 143: 3897-3904, 2002.
30. Gollub EG, Waksman H, Goswami S and Marom Z: Mucin genes are regulated by estrogen and dexamethasone. Biochem Biophys Res Commun 217: 1006-1014, 1995.

31. McGuckin MA, Quin RJ and Ward BG: Progesterone stimulates production and secretion of MUC1 epithelial mucin in steroidresponsive breast cancer cell lines. Int J Oncol 12: 939-945, 1998

32. Hey NA, Graham RA, Seif MW and Aplin JD: The polymorphic epithelial mucin MUC1 in human endometrium is regulated with maximal expression in the implantation phase. J Clin Endocrinol Metab 78: 337-342, 1994.

33. Braga VM and Gendler SJ: Modulation of Muc-1 mucin expression in the mouse uterus during the estrus cycle, early pregnancy and placentation. J Cell Sci 105: 397-405, 1993.

34. Hilkens J, Vos HL, Wesseling J, et al: Is episialin/MUC1 involved in breast cancer progression? Cancer Lett 90: 27-33, 1995.

35. Zaretsky JZ, Barnea I, Aylon Y, Gorivodsky M, Wreschner DH and Keydar I: MUC1 gene overexpressed in breast cancer: structure and transcriptional activity of the MUC1 promoter and role of estrogen receptor alpha (ERalpha) in regulation of the MUC1 gene expression. Mol Cancer 5: 57, 2006.

36. Webster MK, Goya L, Ge Y, Maiyar AC and Firestone GL: Characterization of sgk, a novel member of the serine/threonine protein kinase gene family which is transcriptionally induced by glucocorticoids and serum. Mol Cell Biol 13: 2031-2040, 1993.

37. Buse P, Tran SH, Luther E, Phu PT, Aponte GW and Firestone GL: Cell cycle and hormonal control of nuclearcytoplasmic localization of the serum- and glucocorticoidinducible protein kinase, Sgk, in mammary tumor cells. A novel convergence point of anti-proliferative and proliferative cell signaling pathways. J Biol Chem 274: 7253-7263, 1999.

38. Goya L, Maiyar AC, Ge Y and Firestone GL: Glucocorticoids induce a G1/G0 cell cycle arrest of Con8 rat mammary tumor cells that is synchronously reversed by steroid withdrawal or addition of transforming growth factor-alpha. Mol Endocrinol 7: 1121-1132, 1993.

39. Firestone GL, Giampaolo JR and O'Keeffe BA: Stimulusdependent regulation of serum and glucocorticoid inducible protein kinase (SGK) transcription, subcellular localization and enzymatic activity. Cell Physiol Biochem 13: 1-12, 2003.

40. Bertucci F, Houlgatte R, Benziane A, et al: Gene expression profiling of primary breast carcinomas using arrays of candidate genes. Hum Mol Genet 9: 2981-2991, 2000.

41. Oh IH and Reddy EP: The myb gene family in cell growth, differentiation and apoptosis. Oncogene 18: 3017-3033, 1999.

42. Patel G, Kreider B, Rovera G and Reddy EP: v-Myb blocks granulocyte colony-stimulating factor-induced myeloid cell differentiation but not proliferation. Mol Cell Biol 13: 2269-2276, 1993

43. Gewirtz AM and Calabretta B: A c-myb antisense oligodeoxynucleotide inhibits normal human hematopoiesis in vitro. Science 242: 1303-1306, 1988.

44. Kauraniemi P, Hedenfalk I, Persson K, et al: MYB oncogene amplification in hereditary BRCA1 breast cancer. Cancer Res 60: 5323-5328, 2000.

45. Guerin M, Sheng ZM, Andrieu N and Riou G: Strong association between c-myb and oestrogen-receptor expression in human breast cancer. Oncogene 5: 131-135, 1990.

46. Hodges LC, Cook JD, Lobenhofer EK, et al: Tamoxifen functions as a molecular agonist inducing cell cycle-associated genes in breast cancer cells. Mol Cancer Res 1: 300-311, 2003.

47. King JA, Ofori-Acquah SF, Stevens T, Al-Mehdi AB, Fodstad O and Jiang WG: Activated leukocyte cell adhesion molecule in breast cancer: prognostic indicator. Breast Cancer Res 6: R478-R487, 2004

48. Kester HA, van der Leede BM, van der Saag PT and van der Burg B: Novel progesterone target genes identified by an improved differential display technique suggest that progestin-induced growth inhibition of breast cancer cells coincides with enhancement of differentiation. J Biol Chem 272: 16637-16643, 1997.

49. Wan Y and Nordeen SK: Identification of genes differentially regulated by glucocorticoids and progestins using a Cre/loxPmediated retroviral promoter-trapping strategy. J Mol Endocrinol 28: 177-192, 2002. 